\title{
Stress Evaluation Technique-Cum-Physical Model for Intelligent Helical SMA Spring
}

\author{
Suresh Kumar ${ }^{1}$ \\ ${ }^{1} \mathrm{PhD}$ Student, \\ Department of Mechanical Engineering, \\ YMCA University of Science \& Technology, \\ Faridabad-121006, Haryana, India
}

\author{
M. L. Aggarwal ${ }^{2}$ \\ ${ }^{2}$ Professor, \\ Department of Mechanical Engineering, \\ YMCA University of Science \&Technology, \\ Faridabad-121006, Haryana, India
}

\author{
Lakhwinder Singh ${ }^{3}$ \\ ${ }^{3}$ Professor, \\ Department of Mechanical Engineering, \\ YMCA University of Science \& Technology, \\ Faridabad-121006,Haryana,India
}

\begin{abstract}
In this physical proposed technique-cum-model that enables the stability of intelligent helical SMA spring by defining the various working parameters before its practical implementing as an actuator. Spring-load values which have been also calculated by scale-value. The presented illustration of intelligent helical spring (originally made SMA wire) and parameters included as average load-cell strain values, values of average currents, obtained values of average temperatures, atmospheric temperature changed values and applied voltage values. The various relationships as the minimum value to maximum value relationship for applied voltages and springload values, the maximum value to minimum value relationship for applied voltages and spring-load values, the minimum value to median value relationship for applied voltages and spring-load values, the maximum value to median value relationship for applied voltages and spring load values mentioned with the help of correlations. Then, two model equations are obtained based on minimum value to maximum value $\&$ vice-versa. The working parameters resulted as correlations and minimum value to maximum value $\&$ vice-versa resulted as model equations during the experimentation of intelligent helical spring.
\end{abstract}

Keywords: Annealing, intelligent helical spring/SMA, normalizing, Stability, stress evaluation model.

\section{INTRODUCTION}

NiTi alloys are very famous in recently few years due to large strain setup (8\%) into the internal structure in which temperature or heat used as working parameter [5]. They also are applicable in aerospace and biomedical sciences so researchers consistently focusing on bulk production with minimize costing. The actuation is mainly depends upon the set of control conditions of temperature and applied pressure with the quality of materials used. So, synthesis of NiTi vary from alloy thickness to thickness and applied different methods such as vacuum induction melting electrical are melting, HIP (Hot Isostatic Pressing), elementary power sintering, and mechanical alloying[4]. Segregation, gas absorption and crucible contamination absorption methods were old \& had conventional problems [1]. In recently years, mechanical alloying (MA) technical have been used to reduce the need of precursor materials, control of chemical composition and higher level of porosities. The NiTi compound commonly exhibits two stable phases i.e. 'B2' austenite phase of high-temperature structure and 'B19' martensite phase of low-temperature structure. 'B2' is cubical crystalline structure but ' $\mathrm{B} 19$ ' is monoclinic crystalline structure. The shape memory behavior were firstly observed in 1932 by Olander in his study of "rubber life effect" in the samples of gold-cadmium and in 1938 by Greninger \& Mooradian in their of brass alloys (copper-zinc). Many years later in 1951 Chang \& Read first reported the term shape recovery. They were also working on gold-cadmium alloys. In 1962 William-J-Buebler and his co-workers at naval ordinance laboratory discovered shape memory effect in an alloy of nickel \& titanium. Nowadays, these alloys are becoming the point of interest due to the special characteristics such as shape memory effect, super-elasticity, high tensile strength, wear \& corrosion resistance etc $[2,3]$. Ahmed Frikha, Patrice Cartraud, Fabien Treyssède investigated the static behavior of helical structures under axial loads by taking into account their translational invariance and the homogenization theory [6]. Fabien Treyssède, Ahmed Frikha, Patrice Cartraud again focused on mechanical modeling of helical structures accounting for translational invariance in his part two study. The static behavior had been addressed using a helical homogenization approach which provides the stress state corresponding to axial loads [7]. G.Machado, H.Louche, T.Alonso, D.Favier discussed the mechanical super-elastic behavior of NiTi architecture tube-based NiTi materials subjected to quasistatic compression was studied using two simple cellular samples. They assumed that modeling is very useful for designing and optimizing architectured materials. The super-elastic behavior of two simple architecture materials based on identical tubes[8] Amir Sadjadpour and Kaushik Bhattachary suggested constitutive model for shape-memory alloys that builds on ideas generated from the 
micromechanical studies of the underlying microstructure as a rate-dependant one-dimensional thermodynamically consistent constitutive framework for the dynamic behavior of polycrystalline SMA's[9]. Ferdinando, Auricchio and Davide performed experimental tests on superelastic shape-memory alloys (SMAs) show a significant dependence of the stress-strain relationship on the loading-unloading rate, coupled with a not negligible oscillation of the material temperature [10].

In present work we has used the NiTi wire with a preset conditions as prescribed by the seller and investigation objective to established physical model based on smart helical spring by using the basic electronic components such as registers, capacitors', P-N diodes, transistors, rectifier and also using the electrical components such as sockets, DC supply power, transformers, cables, connectors. This work model can be measure the any helical SMA spring at any predefined condition.

\section{MODEL PREPARATION}

The proposed model comprised of the following main subparts included as:

2.1 Iron-Stand: Iron Stand has been used because it is made of ordinary Iron and easily availability of Iron-pieces in any shape in market or marking college workshop. Further it included following parts:-

Base plate with vertical column: The base plate has dimensions $=18.2 \times 9.5 \times 0.6(0.6 \mathrm{~cm}$ represents the thickness of plate, $9.5 \mathrm{~cm}$ represents width, whereas $18.2 \mathrm{~cm}$ represent length at which vertical column is welded along length). The hole represents in base plate as M7.9X0.375 (dimensions in $\mathrm{mm}$ )

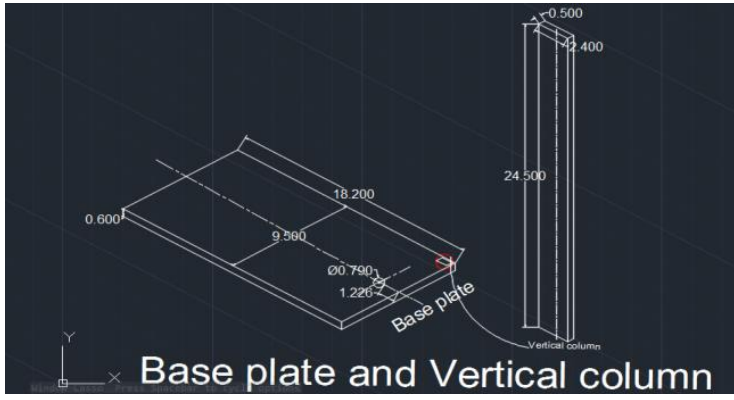

Fig.1 (Base plate)

So it is obvious that width of plate $=9.5$, the vertical column dimension $=24.4 \mathrm{cmX} 0.5 \mathrm{~cm}$ whereas $24.5 \mathrm{~cm}$ represent vertical height of column, $2.4 \mathrm{~cm}$ represent the width of vertical column and $0.5 \mathrm{~cm}$ represent the thickness of vertical column respectively. The base plate also has the threaded hole within itself which is $1.2 \mathrm{~cm}$ far away from width side and vertical column is welded near to the edge of plate as possible as by the tungsten arc welding $\mathrm{m} / \mathrm{c} 400 \mathrm{Amp}$. The tolerance of $\pm 0.1 \mathrm{~mm}$ might be possible, but have no effect of such error.

Cylindrical rod (vertical type): It can be seen from Fig 2, the length of rod is $=28+1+1.7=30.7$, all dimensions are in $\mathrm{cm}$. Here 28 represents the middle portion of rod \&. The thread tap dimension up to $0.6 \mathrm{~cm}$ for $1 \mathrm{~cm}$ length and thread tap dimension up to $1.5 \mathrm{~cm}$ for $1.7 \mathrm{~cm}$ length. The diameter of middle portion $\left(\phi_{\mathrm{m}}\right)=1.2 \mathrm{~cm}$. The dimensions of threaded portion for both sides are M7.9 x1.25 in which outer diameter $\left(\phi_{\mathrm{t}}\right)=7.9 \mathrm{~mm}$
Adjustable lower plate with locking: It consists of cylindrical hollow part. The dimensions of cylindrical hollow part as: length $=2.7 \mathrm{~cm}$, thickness $=0.7 \mathrm{~cm}$, Inner diameter $\left(\phi_{\mathrm{i}}\right)=1.2 \mathrm{~cm}$, Outer diameter $\left(\phi_{\mathrm{o}}\right)=1.2+2 \mathrm{X} 0.7=2.6 \mathrm{~cm}$.

Now for rectangular thick part, the dimensions $=$ 11.5X2.5X0.3 (all dimension in $\mathrm{cm}$ ), the hole dimension of this part include $\phi \mathrm{h}=1.2 \mathrm{~cm}$. The tightened hexagonal nut also used with $0.8 \mathrm{~cm}$ each side and having centralized hole $(\phi)=7.9 \mathrm{~mm}$ such that $\mathrm{M} 7.9 \mathrm{x} 0.375$. The allowance of all meshing parts varies from 0.02 to 0.04 for reading taken in $\mathrm{mm}$. And the dimensions of locking plate $=$ $3.5 \mathrm{~cm} X 1.9 \mathrm{~cm} X 3 \mathrm{~mm}$ whereas $3 \mathrm{~mm}$ represent the

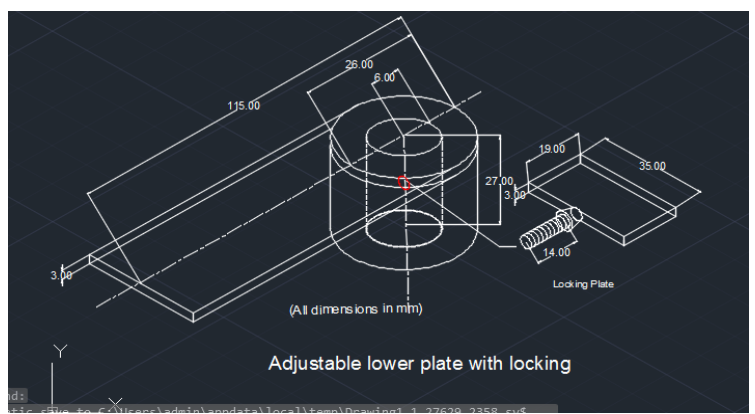

Fig. 2(Lower plate)

thickness of it. Threaded screw length $=1.4 \mathrm{~cm}$. The Ironstand has been made with the help of drilling tool bit and drilling $\mathrm{m} / \mathrm{c}$, lathe $\mathrm{m} / \mathrm{c}$ and its operation, different type of Tap holder \& tap bit (threaded type) and application of tungsten arc welding- $400 \mathrm{amp} \mathrm{m} / \mathrm{c}$ also included.

2.2 Load Cell (20 Kg): It is the transducers which convert force or load into electrical signal. The various types of load cells are commercial available in markets such as Beam type, S-Type, Cantilever type, Tension or Compression type, Straight bar type etc[13].

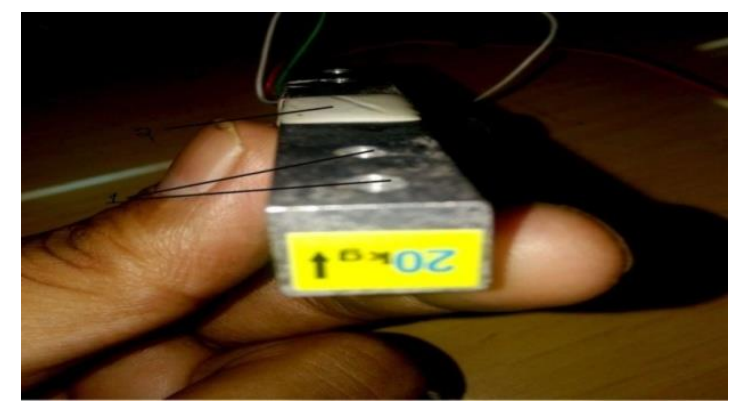

Fig.3 load-cell (Pt. 1 refers for screws and pt. 2 refers for strain-gauges)

The straight bar load cell has been applied here; range from 0 $20 \mathrm{~kg}$ of pressure (force) and it is single point HT sensor.

Specification as-received: Table 1 (Temp. Sensor)

\begin{tabular}{|l|l|l|l|}
\hline $\begin{array}{l}\text { Measuring } \\
\text { Range/ } \\
\text { Rated } \\
\text { capacity }\end{array}$ & $0-20 \mathrm{Kg}$ & Rated output & $1 \mathrm{mV} / \mathrm{V}$ \\
\hline Non-Linearity & $\begin{array}{l}0.15 \% \\
\text { F.S. }\end{array}$ & $\begin{array}{l}\text { Recommended } \\
\text { Excitation } \\
\text { Voltage }\end{array}$ & $12 \mathrm{~V}$ \\
\hline Gauge factor & $2-5$ & $\begin{array}{l}\text { Metal Film/ } \\
\text { Metal Foil }\end{array}$ & Constantan/Silicon \\
\hline
\end{tabular}


The Conversion of force is achieved by measuring the physical deformation of internal strain gauge. The strain gauge configured in a wheat stone bridge circuit. The strain gauges are present in terms of resistors. The load cell or HT sensor has been used here which was single point type specifications mentioned above in table1.

2.3 Temperature Sensor (LM35): A temperature sensor is a device that provides for temperature measurement through an electrical signal. So temperature value measured with respect to volt $(\mathrm{V})$. It is obvious as many types of temperature sensors are available commercially in which few are RTD's, Thermocouples, Thermistors including NTC type and PTC type and semiconductor temperature sensors etc[14]. If we talk about the thermocouple \& RTD's in which both are highly used as per their importance and nature of task being performed.

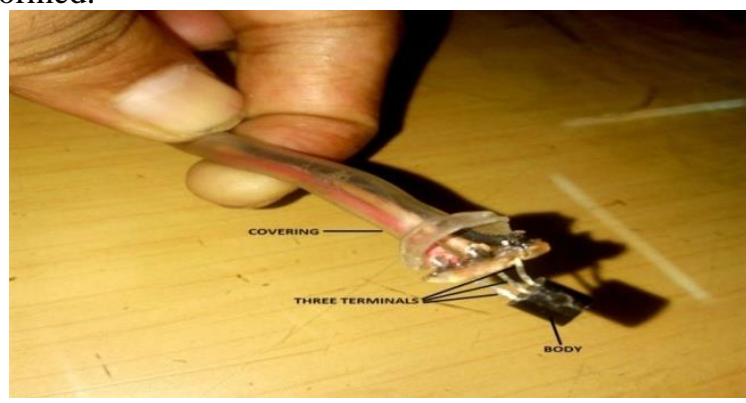

Fig.4(LM35)

In present practical work two LM-35 have been used which is very famous due the especial features of operate range 4-20 volts, calibrated directly in Celsius/centigrade and low cost etc. One has been used for open-atmosphere temperature during the reading and other for SMA reading. LM-35 series are precision integrated-circuit temperature sensors and L-35 also called precision centigrade temperature sensors whose output voltage is linearly proportional to the Celsius/centigrade temperature.

Specification as-received: Table2 (load cell)

\begin{tabular}{|c|c|c|c|}
\hline $\begin{array}{l}\text { Operating } \\
\text { range }\end{array}$ & $4-20$ volts & Non-linearity & $\begin{array}{l} \pm 1 / 4^{\circ} \mathrm{C} \\
\text { (typical) }\end{array}$ \\
\hline Rated range & $\begin{array}{l}-55^{\circ} \\
+150^{\circ} \mathrm{C}\end{array}$ & Self-heating & $\begin{array}{l}0.08^{\circ} \mathrm{C} \\
\text { air only) }\end{array}$ \\
\hline $\begin{array}{l}\text { Linear scale } \\
\text { factor }\end{array}$ & $+10.0 \mathrm{mV} /{ }^{\circ} \mathrm{C}$ & Material ICs & Silicon \\
\hline Colour/Body & Black & $\begin{array}{l}\text { Connecting point } \\
\text { / Connectors }\end{array}$ & $\begin{array}{l}\text { Three (3) (A 4- } \\
20 \text { Volts, B } \\
\text { Output, C } \\
\text { GND) }\end{array}$ \\
\hline
\end{tabular}

The LM35 has an advantage over linear temperature sensors calibrated in ${ }^{\circ} \mathrm{K}$, as the user is not required to subtract a large constant voltage from its output to obtain convenient centigrade scaling. The LM-35 does not require any external calibration.

2.4 Amplifier Circuit (Operational): The load cell had the attachment with strain gauge measuring kit which is basically amplifier circuit and this kit had setup in the work. It includes the IC7107 in which 0-2000 V digital panel meter using seven-segments display driver circuit as seven light emitting diodes.
IC 7107: A high performance and low power consuming integrated circuit (IC) 7107 that consists of seven segments decodes, reference voltage source, comparator and display drives as its internal circuiting[12].

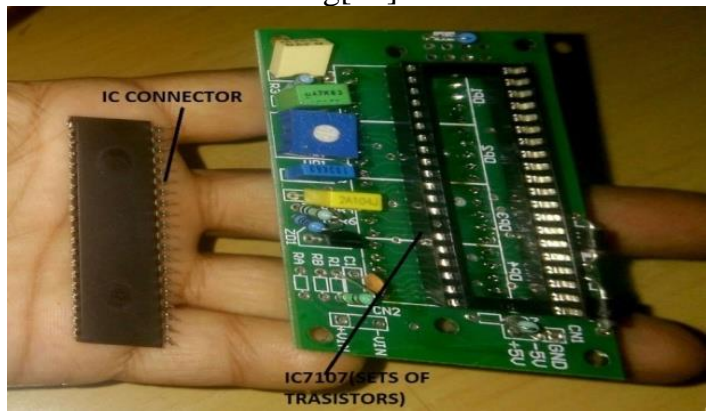

Fig.5(Amplifier circuit)

Digital output value $=0-1999$ (upto 2 volts)

No. of LED in segment $=07$, Display $=7$ segment drive, No. of pin $=40$

Here the increment of count can be calculated using the formula $C O U N T=1000 X V_{I N} / V_{R E F}$

2.5 DC Supply: The power input in the form of direct current has been used in this work for especially the reading of current when DC supply applied to the intelligent helical spring. The unit or component of work measured the voltages in volts on its screen and current in ampere on its screen. It also has the regulator switch in both sides of current \& voltage. The coarse \& final regulating switch had used to final adequate reading and gradually increasing voltage as per requirement. It includes $\mathrm{CV}$ screen \& $\mathrm{CC}$ screen, $\mathrm{CV}$ refers to current voltage \& CC for current and Coarse \& fine regulating switch, Power button( On/Off switch with side fuse),Voltage $=0-15$ volt, Current $=0-5 \mathrm{amp}$. Three connecting point as $+\mathrm{ve}$, -ve \& ground terminal (GND)

2.6 Basic components used: In this present work the components included as Resistors(1k-10k), Capacitor(1000mf/25v,1mf/63v),Diode(Electrolytic),Inductor s(coil/wound), Transistors, (3terminal)Rectifiers(BridgeIN4007 ,Transformers(Set-down909) as shown in fig.5. The sets of diodes here referred to bride type rectifiers[11,12].

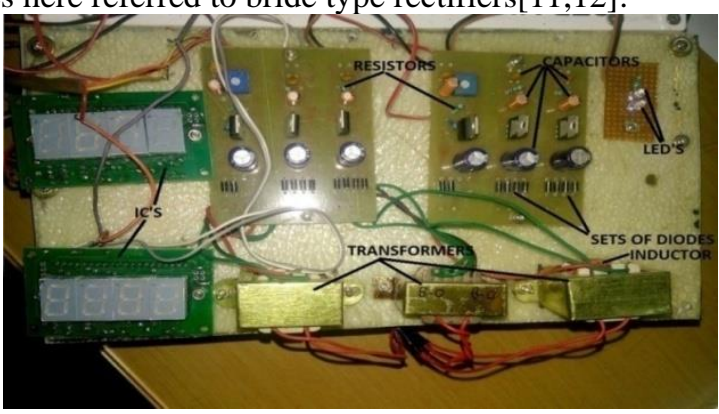

Fig.6(Basic components)

The final model is also shown in the below fig. 7 . 


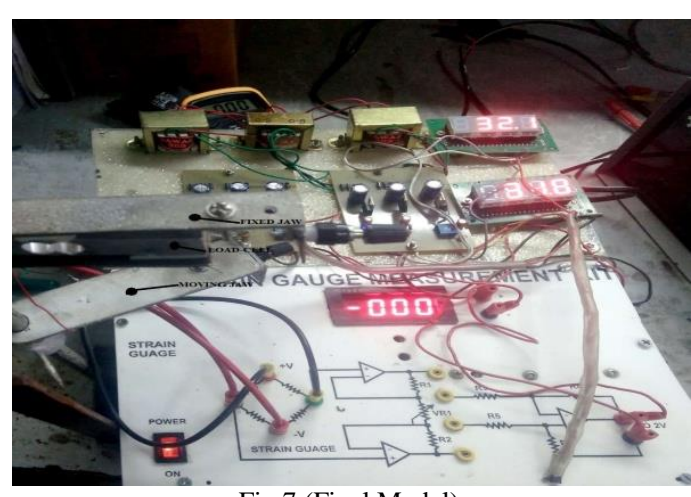

Fig.7 (Final Model)

\section{MATERIAL \& MANUFACTURING OF SMA HELICAL SPRING}

The material of spring wire is flexinol (trade name of NiTi alloy) which behave as smart material. The one way SMA was purchased from the thing bits electronics Pvt. Ltd. as in drawn condition. As-received informing about SMA in composition as $49 \%$ Nickel and $51 \%$ Titanium with one way metallic material, also produced by vacuum induction melting. The flexinol wire of dia $1.0 \mathrm{~mm}$, the manufacturing of SMA helical spring used the threaded screw, end restraints and mild steel fixture with copper clamping wire. The muffle furnace is utilized for the tolerance of $\pm 5^{\circ} \mathrm{C}$ and muffle voltage regulator is set at $530^{\circ} \mathrm{C}$ for 45 minutes to made typical helical spring with mean coil dia. of $7.4 \mathrm{~mm} \mathrm{\&} \mathrm{'} 8$ ' no. of turns. The annealing process was firstly applied by just switch off the muffle furnace and removing the helical spring after 24 hours and then normalized for 6 hours.

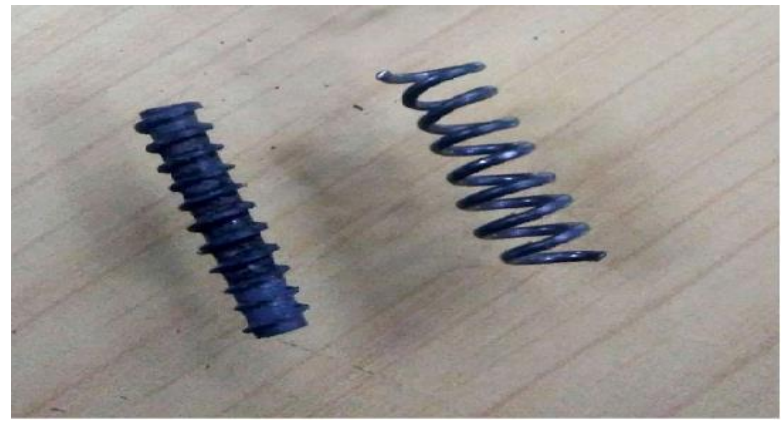

Fig.8 (after annealed \& normalized)

The parameters obtained were as :( D) Mean coil Dia $=7.4$ $\mathrm{mm}$,(d) Wire dia $=1.0 \mathrm{~mm}$, (n) No. of turns $=8$,(c) Spring index $=\mathrm{D} / \mathrm{d}=7.4,\left(\mathrm{~L}_{\text {initial }}\right.$ Initial free length of spring $=2.5 \mathrm{~cm}$

\section{EXPERIMENTAL}

The NiTi SMA helical spring one end had attached with socket terminal. Although socket terminal had maintained fixed also on the top jaw of iron stand and so tightened that not tilted during the loading or unloading. The other end of SMA helical spring had maintained fixed on the movable jaw of iron stand. Preset length condition of SMA helical spring wire represents the vertical length of spring.
Table 3( All main observations)

\begin{tabular}{|c|c|c|c|c|c|c|c|}
\hline $\begin{array}{l}\mathrm{Sr} \\
\dot{\mathrm{N}} \\
\mathrm{o} .\end{array}$ & $\begin{array}{l}\text { Preset } \\
\text { Length( } \\
\text { L) } \\
\text { (cm) }\end{array}$ & $\begin{array}{l}\text { Volta } \\
\text { ge } \\
\text { Appli } \\
\text { ed } \\
\text { (volts } \\
\text { ) }\end{array}$ & $\begin{array}{l}\text { Avg. } \\
\text { Curre } \\
\text { nt in } \\
\text { wire } \\
\text { (Amp. } \\
\text { ) }\end{array}$ & $\begin{array}{l}\text { Atm. } \\
\text { Temperat } \\
\text { ure } \\
\left({ }^{0} \mathrm{C}\right)\end{array}$ & $\begin{array}{l}\text { Avg. } \\
\text { Wir } \\
\text { e } \\
\text { Tem } \\
\text { p. } \\
\text { (0C) }\end{array}$ & $\begin{array}{l}\text { Avg. } \\
\text { Loa } \\
\text { d- } \\
\text { Cell } \\
\text { Stra } \\
\text { in or } \\
\text { GF } \\
\text { valu } \\
\text { e }\end{array}$ & $\begin{array}{l}\text { Sprin } \\
\text { g- } \\
\text { load } \\
\text { value } \\
\text { (gm) }\end{array}$ \\
\hline 1 & 7.5 & 0.2 & 0.93 & 32.9 & 33.1 & 0 & Nil \\
\hline 2 & 7.5 & 0.4 & 1.81 & 32.9 & 33.8 & 0 & Nil \\
\hline 3 & 7.5 & 0.6 & 2.95 & 33 & 34.2 & 0 & Nil \\
\hline 4 & 7.5 & 0.8 & 3.87 & 33 & 35 & 38.5 & $\begin{array}{l}427.3 \\
5 \\
\end{array}$ \\
\hline 5 & 7.5 & 1 & 4.995 & 33 & $\begin{array}{l}36.2 \\
5 \\
\end{array}$ & 76 & 843.6 \\
\hline 6 & 7.5 & 1.2 & 6.12 & 33.1 & 38 & 83 & 921.3 \\
\hline 7 & 7.5 & 1.4 & 7.545 & 33.1 & 40.2 & 90.5 & $\begin{array}{l}1004 . \\
55\end{array}$ \\
\hline 8 & 7.5 & 1.6 & 8.675 & 33 & $\begin{array}{l}48.2 \\
5 \\
\end{array}$ & $\begin{array}{l}110 . \\
5 \\
\end{array}$ & $\begin{array}{l}1226 . \\
55\end{array}$ \\
\hline 9 & 7.5 & 1.8 & 9.97 & 33.1 & 58.5 & 117 & $\begin{array}{l}1298 . \\
7\end{array}$ \\
\hline 10 & 7.5 & 2 & $\begin{array}{l}10.63 \\
5\end{array}$ & 33 & 64.5 & 128 & $\begin{array}{l}1420 . \\
8\end{array}$ \\
\hline
\end{tabular}

For the accuracy of result, the initial Load-Cell value due to the upper plate placed on load-Cell without voltage maintains at 'zero' mm

Spring-load value $=$ Reading of load-Cell value for an applied voltage $X$ Scale value

7.1 Scale-value: The scale values have been calculated with the help of steel slotted weights. The steel hanger weight was $50 \mathrm{gm}$, but the slotted weights of each piece also equal to $50 \mathrm{gm}$. The total $200 \mathrm{gm}$ weight had applied. The hanger placed on socket terminal just simply in the gap of its which is adjustable by turning the cap that present outside and behave like a nut. Placed the slotted weight of $50 \mathrm{gm}$ piece one by one until the weight reached firstly $100 \mathrm{gm}$, then $150 \mathrm{gm}$ and lastly $200 \mathrm{gm}$.

The Avg. scale-value has been calculates as: Set the initial value strain for load-cell $=$ ' 0 '

Strain value of hanger $=05$

Strain value of first weight $(100 \mathrm{gm})=09$

Strain value of last weight $(200 \mathrm{gm})=17$

Table 4(For avg. scale value)

\begin{tabular}{|c|c|c|c|c|c|c|}
\hline $\begin{array}{l}\text { Sr } \\
\mathbf{N} \\
\text { o. }\end{array}$ & $\begin{array}{l}\text { Slott } \\
\text { ed } \\
\text { weig } \\
\text { ht } \\
\text { (gm) }\end{array}$ & $\begin{array}{l}\text { Hangi } \\
\text { ng } \\
\text { weight } \\
\text { (gm) }\end{array}$ & $\begin{array}{l}\text { Loa } \\
\text { d- } \\
\text { Cell } \\
\text { Strai } \\
\text { n or } \\
\text { GF } \\
\text { valu } \\
\text { e }\end{array}$ & $\begin{array}{l}\text { Atm. } \\
\text { Temperatur } \\
\left.\text { e( }{ }^{0} \mathrm{c}\right)\end{array}$ & $\begin{array}{l}\text { Differe } \\
\text { nce } \\
\text { value }\end{array}$ & $\begin{array}{l}\text { Related } \\
\text { value }\end{array}$ \\
\hline 1 & 0 & $50 \mathrm{gm}$ & 5 & 32.3 & 5 & $50 / 05=10$ \\
\hline 2 & 50 & $100 \mathrm{~g}$ & 9 & 32.4 & 4 & $\begin{array}{l}100 / 9=11.1 \\
11\end{array}$ \\
\hline 3 & 100 & 150 & 13 & 32.3 & 4 & $\begin{array}{l}150 / 13=11 . \\
538\end{array}$ \\
\hline 4 & 150 & 200 & 17 & 32.4 & 4 & $\begin{array}{l}200 / 17=11 . \\
765\end{array}$ \\
\hline & & \multicolumn{2}{|c|}{$\begin{array}{c}\text { Avg. scale } \\
\text { value }\end{array}$} & \multicolumn{3}{|c|}{11.1035} \\
\hline
\end{tabular}

Avg. scale-value $=$ (Relative value I+ Relative value II+

Relative value III+ Relative value IV)/4

$=11.10$ 


\section{RESULTS AND DISCUSSION}

The main data obtained in table 3 , firstly the combined relationship of $\mathrm{V}, \mathrm{I}, \mathrm{T}, \mathrm{W}_{\mathrm{t}}$ and $\mathrm{L}_{\mathrm{s}}$ were described as shown in fig. 9 and corresponding table 5 showing the data.

Table 5(Data for V, I, T, $\mathrm{W}_{\mathrm{t}}$ and $\mathrm{L}_{\mathrm{s}}$ )

\begin{tabular}{|c|c|c|c|c|c|}
\hline Sr. No. & V(VOLTS) & I(AMP.) & T(TEMP.) & $\mathbf{W}_{\mathbf{T}}$ & $\mathbf{L}_{\mathbf{s}}$ \\
\hline 1 & 0.2 & 0.93 & 33.1 & 0 & 0 \\
\hline 2 & 0.04 & 1.81 & 33.8 & 0 & 0 \\
\hline 3 & 0.06 & 2.95 & 34.2 & 0 & 0 \\
\hline 4 & 0.8 & 3.87 & 35 & 38.5 & 0.42735 \\
\hline 5 & 1 & 4.995 & 36.25 & 76 & 0.8436 \\
\hline 6 & 1.2 & 6.12 & 38 & 83 & 0.9213 \\
\hline 7 & 1.4 & 7.545 & 40.2 & 90.5 & 1.00455 \\
\hline 8 & 1.6 & 8.675 & 48.25 & 110.5 & 1.22655 \\
\hline 9 & 1.8 & 9.97 & 58.5 & 117 & 1.2987 \\
\hline 10 & 2 & 10.635 & 64.5 & 128 & 1.4208 \\
\hline
\end{tabular}

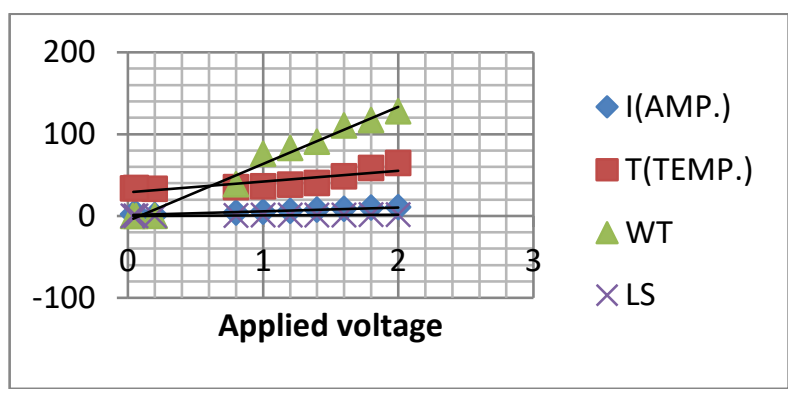

Fig.9

If we considered the minimum value to maximum value for average wire temperatures and average load cell strains readings corresponding to applied voltages as shown in table 6.

Table 6(Minimum value to Maximum value of $\mathrm{W}_{\mathrm{T}}, \mathrm{L}_{\mathrm{S}}$ )

\begin{tabular}{|c|c|c|c|}
\hline Sr. No. & Voltage(V) & $\begin{array}{c}\text { Avg.Wire } \\
\left.\text { Temperature( } \mathrm{W}_{\mathrm{T}}\right) \\
(0 \mathrm{C})\end{array}$ & $\begin{array}{c}\text { Avg. Load-Cell Strain } \\
\text { or GF value(LS) }\end{array}$ \\
\hline 1 & 0.8 & 35 & 38.5 \\
\hline 2 & 1 & 36.25 & 76 \\
\hline 3 & 1.2 & 38 & 83 \\
\hline 4 & 1.4 & 40.2 & 90.5 \\
\hline 5 & 1.6 & 48.25 & 110.5 \\
\hline 6 & 1.8 & 58.5 & 117 \\
\hline 7 & 2 & 64.5 & 128 \\
\hline
\end{tabular}

The minimum value to maximum value relationship for average wire temperatures and average load cell strains corresponding to applied voltages is shown graphically as in fig.9.

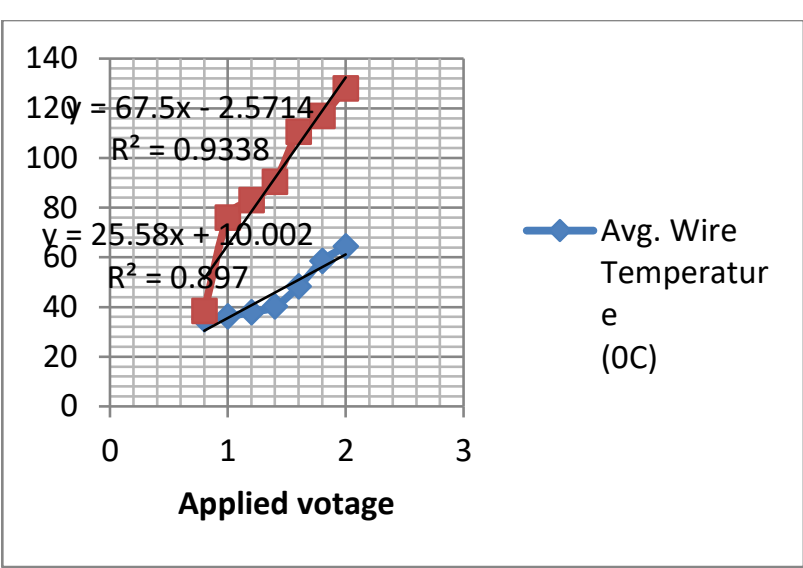

Fig.10 (Minimum value to Maximum value of $\mathrm{W}_{\mathrm{T}}, \mathrm{L}_{\mathrm{S}}$ )

The correlations obtained as:

$\mathrm{Y}=67.5 \mathrm{x}-2.571, \mathrm{R}^{2}=0.933 \ldots \ldots$ (i) For $\mathrm{W}_{\mathrm{T}}$ $\mathrm{Y}=25.58 \mathrm{x}+10.00, \mathrm{R}^{2}=0.897 \ldots \ldots$ (i) For $\mathrm{L}_{\mathrm{s}}$

Here ' $R$ ' represents the correlation coefficients.

It can be seen from the fig.9, red colour indicate the variation of $\mathrm{W}_{\mathrm{T}}$ (Avg. wire temperature) corresponding to the value against applied voltage and also blue colour indicates the variation of $\mathrm{L}_{\mathrm{S}}$ (avg. load cell strain) corresponding to the value against applied voltage in the above mention graph.

8.1 The minimum value to maximum value relationship for Avg. current in SMA wire which is measured in ampere and avg. load cell value in $\mathrm{mm}$.

Table 7(data for Avg. current \& GF value)

\begin{tabular}{|c|c|c|}
\hline Sr. No. & Avg. Current (Amp.) & Avg. Load-Cell Strain or GF value \\
\hline 1 & 3.87 & 38.5 \\
\hline 2 & 4.995 & 76 \\
\hline 3 & 6.12 & 83 \\
\hline 4 & 7.545 & 90.5 \\
\hline 5 & 8.675 & 110.5 \\
\hline 6 & 9.97 & 117 \\
\hline 7 & 10.635 & 128 \\
\hline
\end{tabular}

The seven readings have been considered as shown in table 7 above.

\section{Avg. current(Amp.) V/s Avg. Load- Cell Strain or GF value}

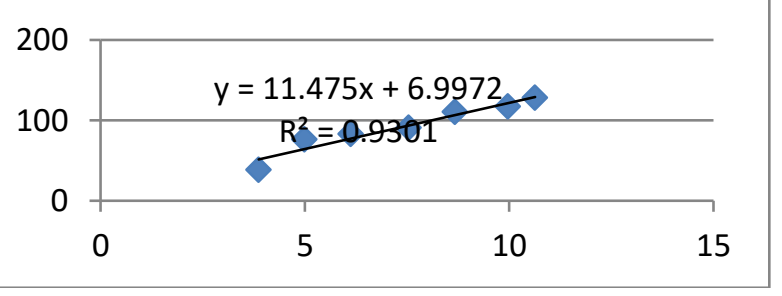

Fig.11

The correlations obtained as:

$Y=11.47 x+6.997, R^{2}=0.930 \ldots$ (iii)

8.2 The minimum value to maximum value relationship for applied voltage and avg. spring-load value measured in volts and $\mathrm{Kg}$. 
Table 8 (data for Voltage (Volts) \& Spring-load value)

\begin{tabular}{|c|c|c|}
\hline Sr. No. & Voltage (Volts) & Spring-load value \\
\hline 1 & 0.8 & 0.42735 \\
\hline 2 & 1 & 0.8436 \\
\hline 3 & 1.2 & 0.9213 \\
\hline 4 & 1.4 & 1.00455 \\
\hline 5 & 1.6 & 1.22655 \\
\hline 6 & 1.8 & 1.2987 \\
\hline 7 & 2 & 1.4208 \\
\hline
\end{tabular}

The seven readings also have been taken again from table 3 as shown in table 8 above.

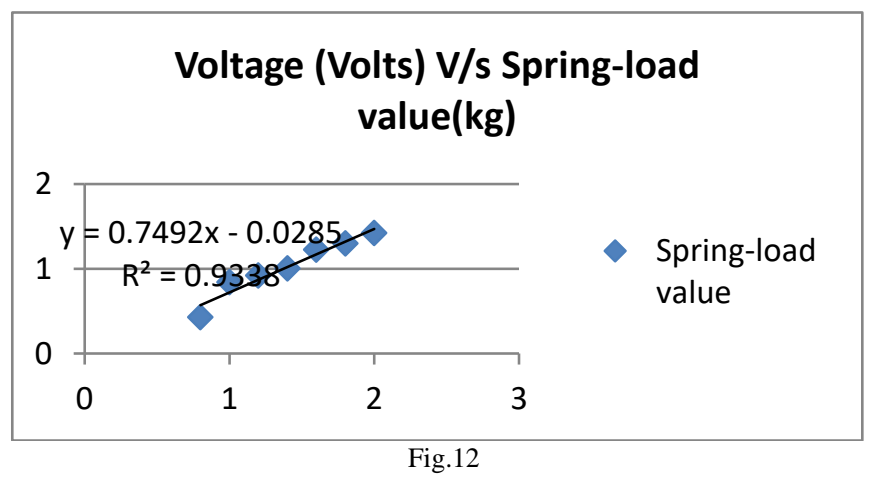

The correlations obtained as:

$$
Y=0.749 x+0.028, R^{2}=0.933 \ldots \ldots \text { (iv) }
$$

The same correlation was obtained due to no change of data but used to the find the avg. load model equation in case of maximum value to minimum value relationship for applied voltage $(\mathrm{V})$ and spring-load value $\left(\mathrm{W}_{\mathrm{T}}\right)$.

8.3 The minimum value to Median value relationship for applied voltage and spring-load value

Table 9( data for Volts \& $\mathrm{W}_{\mathrm{T}}$ )

\begin{tabular}{|c|c|c|}
\hline Sr. No. & Voltage(Volts) & Spring-load value( $\left.\mathrm{W}_{\mathrm{T}}\right)$ \\
\hline 1 & 0.8 & 0.42735 \\
\hline 2 & 1 & 0.8436 \\
\hline 3 & 1.2 & 0.9213 \\
\hline 4 & 1.4 & 1.00455 \\
\hline
\end{tabular}

Four readings had considered as median in 7 values must be 4 th.

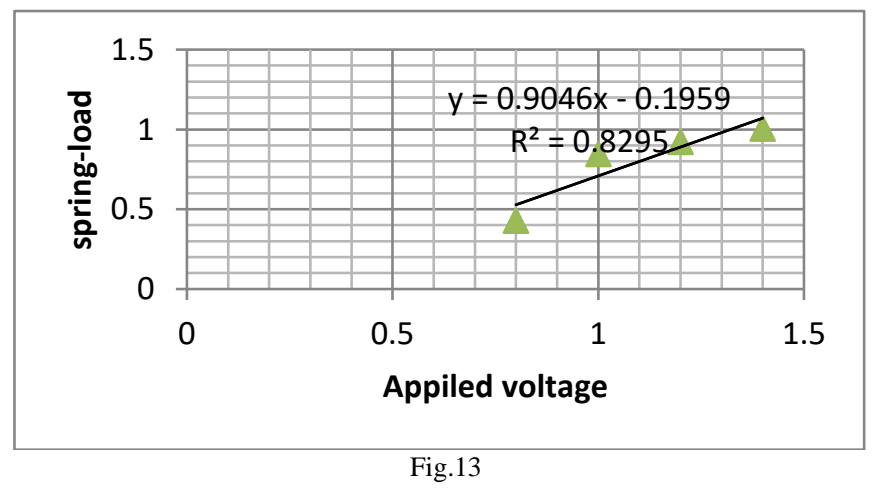

The correlations obtained as:

$\mathbf{Y}=\mathbf{0 . 9 0 4 x - 0 . 1 9 5 ,} \mathbf{R}^{2}=\mathbf{0 . 8 2 9} \ldots$..(iv) For $V \&$ Ws

8.4 The maximum value to Median value relationship for applied voltage and spring-load value

Table 10(data for Volts \& Spring-load value)

\begin{tabular}{|c|c|c|}
\hline Sr. No. & Voltage(Volts) & Spring-load value $\left(\mathrm{W}_{\mathrm{T}}\right)$ \\
\hline 1 & 2 & 1.4208 \\
\hline 2 & 1.8 & 1.2987 \\
\hline 3 & 1.6 & 1.22655 \\
\hline 4 & 1.4 & 1.00455 \\
\hline
\end{tabular}

Here again four readings had considered as median must be 4 reading.

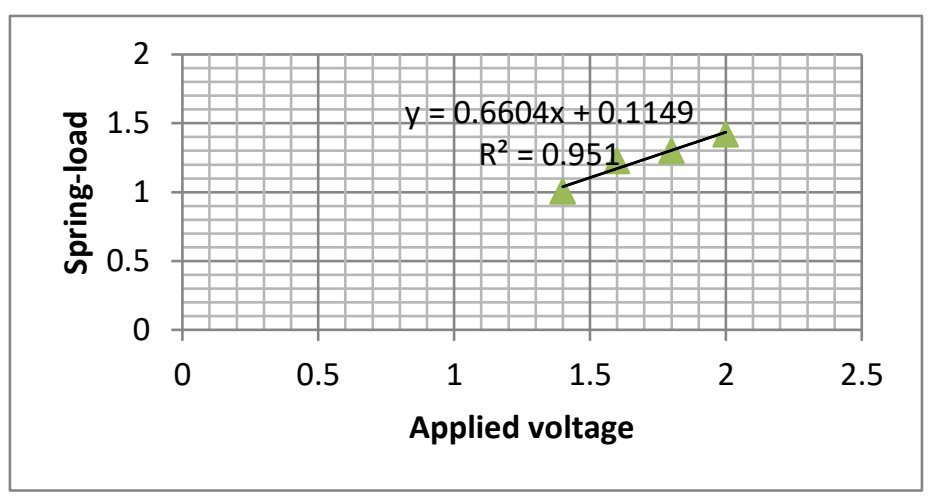

Fig.14

Furthermore,

For Stress-values of intelligent helical spring SMA

Initially the spring was formed which have dimensions as:

Mean coil Dia $=7.4 \mathrm{~mm} \&$ Wire dia $=1.0 \mathrm{~mm}$, but fact is that spring deformed axially throughout according to length, so no. of turns \& spring index have been changed. This $1.0 \mathrm{~mm}$ wire has stiffness value at room temperature, or we can say deformed position of spring in which martensite only stable phase is exist.

In present work the measured value of Initial Vertical length of spring $\left(\left(\mathrm{L}_{\mathrm{iv}}\right)=2.5 \mathrm{~cm}\right.$

Measured increased value of Final Vertical length of spring $\left(\left(\mathrm{L}_{\mathrm{fv}}\right)=7.5 \mathrm{~cm}\right.$, Mean coil diameter $=7.4$

From Table 3,

$7.4 / 10=0.74 \mathrm{~mm}$

Spring Index $(C)=D / d=0.74 / 1.0=0.74$

Shear stress factor $\left(\mathrm{K}_{\mathrm{s}}\right)=1+1 / 2 \mathrm{C}=1+1 /(2 * 0.74)=1+$ $0.676=1.676$

\subsection{Resultant Stress $\left(\tau_{\mathrm{rs}}\right)$ calculation:}

We know that experimental helical spring behave like as an compression spring as at applied voltages the currents passes throughout wire and try to became full helical spring so forced imparted direction towards the each other or we can say lower end of wire try to move in upper direction and upper end of wire try to move in downward direction. Imaginary resultant stress equations $\left(\tau_{\text {irs }}\right)$ have been calculated from data mentioned in experimental work based on voltages \& spring-loads values of intelligent helical spring SMA.

From the given Table 3, The Minimum and maximum Springload values referred to the forth reading for the 0.80 volts and $10^{\text {th }}$ reading for the 2.00 volts. 
The Imaginary resultant stress $\left(\tau_{\text {irs }}\right)$ can be calculated as:

$=\left(8 \times\right.$ Load $x$ Spring Index x $\left.\mathrm{K}_{\mathrm{s}}\right) /\left(\Pi \mathrm{x} \mathrm{d}^{2}\right) \ldots$. (i)

Where

'load' is denoted by $\mathrm{F}$ or $\mathrm{W}$ in Newton or $\mathrm{kg}$,

'Spring Index' is denoted by $\mathrm{C}$,

'Shear stress factor' is denoted by $\mathrm{K}_{\mathrm{s}}$,

'Wire dia.' is denoted by d

'Mean coil dia.' Is denoted by D

For the Minimum Resultant stress value

Again from Table 1, applied voltage $=0.80$ volts and correspondingly given value of

Spring-load value $=427.35 \mathrm{gm}=427.35 / 1000 \mathrm{~kg}=$

$0.42735 \mathrm{~kg}$

Spring Index $(C)=0.74$

Shear stress factor $\left(\mathrm{K}_{\mathrm{s}}\right)=1.676$

Using ' $\Pi$ 'value equal to $22 / 7$

Wire diameter $=1.0 \mathrm{~mm}$

Here, substituting the values in equation no. (i), we get

$=\left(8 \times\right.$ Load $x$ Spring Index $x \mathrm{~K}_{\mathrm{s}} /\left(\Pi \times \mathrm{x}^{2}\right)$

$=(8 \times 0.42735 \times 0.74) /\left(22 / 7 * 1.0^{2}\right)$

$=2.529912 / 3.142875=0.804967 \approx \mathbf{0 . 8 0 5}$

\section{For the Maximum Resultant stress value}

In above mention row, applied voltage $=2.0$ volts and correspondingly given value of

Spring-load value $=1420.80 \mathrm{gm}=1420.80 / 1000 \mathrm{~kg}=$ $1.4208 \mathrm{~kg}$

Now again considering, Spring Index $(C)=0.74$

Shear stress factor $\left(\mathrm{K}_{\mathrm{s}}\right)=1.676$

Using ' $\Pi$ 'value equal to $22 / 7$

Wire diameter $=1.0 \mathrm{~mm}$

Here, substituting the values in equation no. (i), we get

$=\left(8 \times\right.$ Load $x$ Spring Index $x \mathrm{~K}_{\mathrm{s}} /\left(\Pi \mathrm{x} \mathrm{d}^{2}\right)$

$=(8 \times 1.4208 \times 0.74) /\left(22 / 7 * 1.0^{2}\right)$

$=8411136 / 3.142875=2.6762255 \approx \mathbf{2 . 6 7 6} \ldots .$. (vi)

(The minimum resultant stress value and maximum resultant stress value were obtained as Imaginary Resultant Stress $\left.\left(\tau_{\mathrm{rs}}\right)\right)$

\subsection{Model Equations}

This model equation based on data mention in

Experimental work as:

\section{First model equation}

This equation is based on Avg. load relation for Min. value to max. value or vice-versa:

Let considering,

Load equation $\left(\mathrm{Y}^{\mathrm{I}}\right)=$ Min. value to max. value

Load equation $\left(\mathrm{Y}^{\mathrm{II}}\right)=$ Max. value to min. value

$\operatorname{Avg} \operatorname{Load}\left(\mathbf{Y}_{\mathrm{AL}}\right)=\left[\left(\mathrm{Y}^{\mathrm{I}}\right)+\left(\mathrm{Y}^{\mathrm{II}}\right)\right] / 2$

$$
\begin{aligned}
& =(0.749 \mathrm{x}+0.749 \mathrm{x}) / 2-(0.0 .28+0.028) / 2 \\
\mathbf{Y}_{\mathrm{Al}} & =\mathbf{0 . 3 7 4 5} \mathbf{x}-\mathbf{0 . 0 1 4}
\end{aligned}
$$

In helical spring,

Spring force $\left(\mathrm{F}_{\mathrm{s}}\right)=-\mathrm{k} . \delta$

If the one-dimensional deflection of spring in which ' $\delta$ ' represents the deflection of spring and ' $k$ ' represents the spring constant, so we can write

$\left(\mathbf{F}_{\mathrm{s}}\right)=\mathbf{Y}_{\mathrm{Al}}=\mathbf{0 . 3 7 4 5 \mathrm { x } - 0 . 0 1 4}$
This equation is based on Avg. load relation for Min. value to median value and max. value to median value:

Let considering,

Load equation $\left(\mathrm{Z}^{\mathrm{I}}\right)=$ Min. value to median value

Load equation $\left(Z^{\mathrm{II}}\right)=$ Max. value to median value

$\operatorname{Avg.~Load~}\left(\mathbf{Z}_{\mathrm{AL}}\right)=\left[\left(\mathrm{Z}^{\mathrm{I}}\right)+\left(\mathrm{Z}^{\mathrm{II}}\right)\right] / 2$

$$
=(0.904 \mathrm{x}-0.195+0.660 \mathrm{x}+0.114) / 2
$$$$
=(1.564 \mathrm{x}-0.081) / 2
$$

$\mathbf{Z}_{\mathrm{AL}}=\mathbf{0 . 7 8 2 \times - 0 . 0 4 0 5}$

Again we can write for one-dimensional deflection

$\left(F_{\mathrm{s}}\right)=\mathrm{Z}_{\mathrm{AL}}=0.782 \mathrm{x}-\mathbf{0 . 0 4 0 5}$

Imaginary deflections $\left(\mathrm{X}_{1}, \mathrm{X}_{2}, \ldots.\right)$

Experimental calculations used the final length

$\mathrm{L}_{\text {initial }}=2.5 \mathrm{~cm}=$ Initial free length of SMA

$\mathrm{L}_{\text {final }}=7.5 \mathrm{~cm}=$ final free length of $\mathrm{SMA}=$ Preset length of

SMA spring

Deflection $\left(\mathrm{X}_{1}\right)=\mathrm{L}_{\text {final }}-\mathrm{L}_{\text {initial }}=7.5-2.5$

First deflection $\left(\mathrm{X}_{1}\right) \quad=5.0 \mathrm{~cm}$ (data included)

$\mathrm{L}_{\text {initial }}=2.5 \mathrm{~cm}=$ Initial free length of SMA

$\mathrm{L}_{\text {final }}=6.5 \mathrm{~cm}=$ final free length of $\mathrm{SMA}=$ Preset length of

SMA spring

Deflection $\left(\mathrm{X}_{2}\right)=\mathrm{L}_{\text {final }}-\mathrm{L}_{\text {initial }}=6.5-2.5$

Second deflection $\left(\mathrm{X}_{2}\right) \quad=4.0 \mathrm{~cm}$ (data not included)

Deflections $=X_{1}=5.0 \& X_{2}=4.0$, must be equal to the Height $(\mathrm{H})$ of weight/ load falling according to the gravity in one direction, so we can write

Height of Falling $\operatorname{load}(P)=$ Deflections $=X_{1}$ or $X_{2} \ldots \ldots$ (ix)

(If initial height not considered)

These above (vii),(viii) \&(ix)equations help to find the work done in springs $\left(\mathrm{W}_{\mathrm{s})}\right.$ which to bear the calculated Load $\mathrm{fr}$ For example, in spring, Work done of single spring(onedimensional loading only)

$$
\begin{aligned}
\mathrm{W}_{\mathrm{s}} & =\int_{\text {initial }}^{\text {final }}(\mathrm{Fs}) \cdot d \delta \\
& =\int_{\text {initial }}^{\text {final }}(-\mathrm{k} \cdot \delta) \cdot d \delta \\
& =-1 \mathrm{k} / 2\left[\left(\delta_{\text {initial }}\right)^{2}-\left(\delta_{\text {final }}\right)^{2}\right]
\end{aligned}
$$

Work done by two springs (one-dimensional loading)

$$
\begin{aligned}
& \mathrm{W}_{\mathrm{s} 1}=\int_{\text {initial }}^{\text {final }}-\left(\mathrm{k}_{1}+\mathrm{k}_{2}\right) \cdot \mathrm{d} \delta \text { (for } \mathrm{II}^{\mathrm{rl}} \text { condition) } \\
& \mathrm{W}_{\mathrm{s} 1}=\int_{\text {initial }}^{\text {final }}-\left(1 / \mathrm{k}_{1}+1 / \mathrm{k}_{2}\right) \cdot \mathrm{d} \delta \text { (for series) }
\end{aligned}
$$

For New design of helical spring necessary parameters are $\mathrm{d}$ (wire dai.), $\mathrm{D}$ (mean coil dia.) and $\mathrm{P}$ (load simply knowing $\mathrm{k}$ and calculated load $(\mathrm{P})=\mathbf{Y}_{\mathrm{Al}}=\mathbf{Z}_{\mathrm{AL}}$. The resultant shear stress also calculated with or without considering the stress concentration in inside fibre of coil.

Above three equations also help to find P.E of falling load(P), K.E of falling load(P) and also which types of damping of load $(\mathrm{P})$ required during falling (all in one-dimensional loading only).

\section{CONCLUSIONS}

This Physical model enables the stability of intelligent helical SMA spring by defining the various working parameters before its practical implementing as an actuator. It also enables to the design of single spring or no. of springs based on the SMA. It includes

1. The various relationships with the help of correlations for the minimum value to maximum value relationship for applied voltages and spring- 
load values, the maximum value to minimum value relationship for applied voltages and spring-load values, the minimum value to median value relationship for applied voltages and spring-load values, the maximum value to Median value relationship for applied voltages and spring-load values as equations 'iii', 'iv', ' $v$ ' and 'vi' are evaluated.

2. The model equations are based Imaginary resultant stresses for data available for $1.0 \mathrm{~mm}$ wire as

(i) Equation 'vii' is based on Avg. load relation for Min. value to max. value or vice-versa:

(ii) Equation 'vii' is based on Avg. load relation for Min. value to median value and max. value to median value.

This prescribed work will be helpful to researchers as an alternative to evaluate SMA helical spring working parameters or SMA running condition helical spring/wire before implementing in the form of actuator in any system.

\section{REFERENCES}

[1] Elahinia MH Hashemi M, Tabesh M, ec of manufacturing and processing of NiTi Implants: A review [J]. preg. Master. Sci. 2012, 57(5):911-946

[2] Seyyed aghamiri SM, atimadabadi MN, raygan S1 combined effects of different heat treatments and $\mathrm{Cu}$ elements of transformation behavior of NiTi crtnodontic wire (J). J.Mech behave bioned mater 2011, 4(3):298-302.

[3] Piquard R, D A cunto A, Laheurte P, et of micro end milling of NiTi biomedical alloy, burn formation \& phase transformation $[\mathrm{J}]$ précis Eng., 2014, 38(2):356-364.

[4] A R sadeghi, is mostajabodavch et. Of milling \& heat treatment of the systhesis of NiTi power, journal of Wu has university of technology- mater Sci. Fd., Oct 2017, Vol 32 No5:1156-1162.

[5] https://nptel.ac.in/vedio/smart material/SMA.

[6] Ahmed Frikha, Patrice Cartraud, Fabien Treyssède (2013), Mechanical modeling of helical structures part 1, International Journal of Solids and Structures, Vol. 50, pp. 1373-1382.

[7] Fabien Treyssède, Ahmed Frikha, Patrice Cartraud(2013), Mechanical modeling of helical structures part 2, International Journal of Solids and Structures, Vol. 50, pp. 1383-1393.

[8] G.Machado, H.Louche, T.Alonso, D.Favier(2015), superelastic cellular NiTi tube-based materials: Fabrication, experiments and modeling, Elsevier, Journal of Materials and Design, Vol. pp. 212 220.

[9] Amir Sadjadpour and Kaushik Bhattachary, A micromechanics inspired constitutive model for shape- memory alloys: The onedimensional case, Division of Engineering and Applied Science, California Institute of Technology, june 29, 2005.

[10] Ferdinando, Auricchio and Davide fugazza, Journal of intelligent material systems and structures, Vol. 19, 2008.

[11] W.Bolton, Electronic control systems in mechanical and electrical engg., fourth edition, pearson, 2017.

[12] J.B. Gupta, basic electrical and electronics engg., fourth edition, s.k. kataria \& sons, 2005.

[13] https:www/loadcell/vedio/types/applicability/pdf.

[14] https:www/temperaturesensor/vedio/types/applicability/pdf. 